\title{
J.R.R. TOLKIEN'S CONSTRUCTION OF MULTIPLE MASCULINITIES IN THE LORD OF THE RINGS
}

\author{
Beatriz Domínguez Ruiz, Universidad de Granada ${ }^{1}$ \\ Email: beatrix@correo.ugr.es
}

\begin{abstract}
The Lord of the Rings is one of the most widely acclaimed fantasy novels in history and since it was first published in the fifties, the analysis of the work from the perspective of gender has mainly focused on its female characters. In this article, written on the $60^{\text {th }}$ anniversary of the first publication of the third and last volume, The Return of the King, my aim is to focus rather on the most relevant male characters and what types of masculinities they perform, offering thus a new re-reading of the text from the point of view of masculinities.

Keywords: Tolkien, The Lord of the Rings, gender, dominant hegemonic masculinity, alternative masculinities, obsolete masculinities

Title in Spanish: "La construcción de masculinidades múltiples en El Señor de los Anillos, de J.R.R. Tolkien"

Resumen: El Señor de los Anillos es una de las novelas de fantasía más aclamadas de la historia. Desde que fue publicada en los cincuenta, el análisis de esta obra desde el punto de vista del género se ha centrado fundamentalmente en las mujeres. En este artículo, escrito en el sexagésimo aniversario de la primera publicación del tercer y último volumen de la obra, El Retorno del Rey, mi intención es centrarme sin embargo en los tipos de masculinidades representados por algunos de los personajes más relevantes, ofreciendo una nueva relectura del texto desde el punto de vista de las masculinidades.

Palabras clave: Tolkien, El Señor de los Anillos, género, masculinidad hegemónica dominante, masculinidades alternativas, masculinidades obsoletas.
\end{abstract}

Published in three different volumes between 1954 and 1955, The Lord of the Rings has been analyzed since then from a wide variety of perspectives: sociology, psychology, history, literature and, above all, recently, gender and eco-criticism. It is hardly surprising that it was chosen as the most widely acclaimed book of the $20^{\text {th }}$ century in a poll carried out by Waterstone's and the BBC Channel Four, as a result making Tolkien the "author of the century." Although Tom Shippey, one of Tolkien's experts, actually claims that he is one of the most underrated authors, probably because fantasy is still regarded nowadays as a secondary genre and not "real literature," sixty years after its publication, J.R.R. Tolkien's Middle-earth, its characters and its sources are still objects of study and analysis for students,

Date of reception: 23 July 2015

Date of acceptance: 10 September 2015 
scholars and critics alike. Peter Jackson's film adaptation of the book at the beginning of the $21^{\text {st }}$ century, together with his recent adaptation of The Hobbit have probably contributed to making the Oxford scholar's masterpiece more present than ever.

Although the analysis of the novel from the point of view of gender is not completely original, ${ }^{2}$ it seems that the academia and even fandom literature have focused mainly on the main female characters of the novel, and it has not been until relatively recently that authors like Holly A. Crocker (2005) or Melanie Rost (2011) have focused mainly on masculinities. This article aims thus to offer some of the conclusions I have reached in my current research concerning the most common and different patterns of masculinities performed by some relevant characters in Tolkien's masterpiece, following some recent ideas promoted by Stephen M. Whitehead (2002) or Josep M. Armengol (2006).

The world of Middle-earth is undoubtedly male-dominated - at a first perfunctory glance it is only obvious that the Fellowship of the Ring, whose task is to destroy the One Ring that Sauron longs to have in order to save the world they know from evil, are all male characters: the Men Boromir and Aragorn, the Elf Legolas, the Dwarf Gimli, the Wizard Gandalf and the four Hobbits Frodo, Sam, Merry and Pippin. Whereas some critics have used this and other facts concerning the scarcity of female characters in the novel to brand Tolkien as a misogynist, there are others who have justified the appearance of very few women in the plot as a reflection of his personal background and the main literary sources that the author revered, namely Anglo-Saxon and Scandinavian texts.

Existing criticism on the works of Tolkien put forward the idea that some of the situations he endured in his life were extremely relevant for the creation of Middle-earth and the War of the Ring. The fact whether a writer's biography is essential or not to understand his/her works is still debatable nowadays. Notwithstanding, in the case of Tolkien, some insight into his biography can lead to a better understanding of the fantasy world he created and also to the patterns of masculinity he constructed in it: although a priori we may expect the text to be an array of examples of masculinities present in his time or the texts he either taught or preferred reading, this should not be taken for granted, as this article will try to explain. A re-reading of the book is therefore necessary from the point of view of gender, as it entails, according to Armengol, "not only questioning patriarchal masculinities in literary texts but also challenging former traditional critical readings of these texts" (2006: 266). Moreover, what I would like to show with this re-reading of The Lord of the Rings is how the so-called "crisis of masculinity," which has been under debate since the end of the nineties in the studies of masculinities, can be partly found in Middle-earth. John MacInnes believes that masculinity has been in crisis from the very beginning as "this invention of masculinity was essentially a holding operation," and it has been in crisis because

the essence of masculinity can never be grasped or defined. If it comprises essentially social characteristics or capacities, we have to explain on what grounds women have been incapable of,

\footnotetext{
The literature concerning female characters in The Lord of the Rings since the book was published in the 50s has been quite varied: from Catharine Stimpson (1969) and Brenda Partridge (1983), who criticized the author for "creating" traditional stereotypes and even accused him of misogyny, to Edith L. Crowe (1995) or Lisa Hopkins (1995), who praise the representation of characters like Galadriel or the appearance of feminine traits in some male characters, as will be discussed in this article.
} 
or prevented from, acquiring them. Masculinity is something for the girls as much as the boys, and over time, it must surely come to have no special connection to either biological sex (1998: 45).

There is therefore, indeed, a change of ideals that dissociate the binary dichotomy men/masculine and women/feminine. In Middle-earth, at the end of the Third Age and the beginning of the Fourth, we can see how some values are in "crisis," those that have usually been ascribed to a type of hegemonic masculinity. The relevance of this assertion is that Tolkien seemed to have perceived the end of hypermasculinity, which is what we find in The Lord of the Rings, when he wrote his book in the first half of the twentieth century.

Born in a heteronormative society that socially imposed the traditional Western heterosexualized norm of "men are masculine and women are feminine," Tolkien is the perfect representative of the Oxford of the 30s, the academic atmosphere and society that we also find in other works, such as Evelyn Waugh's Brideshead Revisited. Raised under some patriarchal and religious assumptions that women were "temptation," with the fear of the feminine pervading men's lives, Tolkien formed at the beginning of the $20^{\text {th }}$ century special bonds with other same-sex peers, who led him to belong to literary groups of only men: the T.C.B.S. (Tea Club and Barrovian Society) with some friends at King Edward's School (Birmingham), the Coalbiters and the Inklings in Oxford when he started working for the University of Oxford. It seems only reasonable to infer that Tolkien was completely at ease in the company of other men personally and professionally, homosocial relationships were a prevailing characteristic in his life.

Concerning gender, Judith Butler already understood it as a social construct and as performative in the nineties, considering that

[g]ender is not always constituted coherently or consistently in different historical contexts, and because gender intersects with racial, class, ethnic, sexual, and regional modalities of discursively constituted identities. As a result, it becomes impossible to separate out 'gender' from the political and cultural intersections in which it is invariably produced and maintained (1999: 6).

Masculinities are therefore a social construct and they are also multiple, as R.W. Connell already put forward in 1995 by preferring to use the plural term, for we cannot speak about one unique type of masculinity, thus Connell referred to hegemonic and subordinated or nonhegemonic masculinities (1995: 242). He went on to state that "masculinities are configurations of practice that are constructed, unfold, and change through time" (2005: 24), so those that appear in The Lord of the Rings vary not just from one race to another but also even among characters of the same race and as the plot progresses. As Hearn and Collinson outline, "various men and masculinities may be defined in relation to other men, other masculinities, women, femininities, or some further difference(s). It is not possible to produce a complete taxonomy" (1994: 108-109). As there is a wide diversity of variables that influence a person's behaviour, it is interesting to see how Sandra Ballif Straubhaar defines Tolkien's world as "polycultural, polylingual" (2004: 112) and at the same time, it is hierarchical, as is shown in the Fellowship of the Ring, where there is a representative of each race, all of them belonging to a certain social elite. ${ }^{3}$ It is therefore essential to

3 Gandalf is one of the most powerful members of the Istari, Legolas is the son of the king of the Silvan Elves 
understand who these characters are, but, above all, what they do and how they behave, because together with some situations they will endure and the relationships established among them, they will prove highly relevant and influential in the performance of their masculinities, for as Butler states, it is what you do that matters (1999: 178-179).

Masculinity is therefore perceived as dynamic and changeable, in line with Hearn's and Collinson's constructionist and performative view that it fluctuates throughout time and is influenced by all sorts of variables: age, appearance, bodily facility, care, economic class, ethnicity, fatherhood, relations to biological reproduction, leisure, martial and kinship status, mind, occupation, place, religion, sexuality, size and violence (1994: 108). Considering these variables, what kind of masculinities did Tolkien construct for the most relevant characters in Middle-earth and how can they be regarded sixty years after the publication of the book?

Within the multiple masculinities of Middle-earth, there are two that stand out from the rest and seem to comprise the main characters. Whereas the first pattern, undoubtedly based on a traditional dominant hegemonic masculinity, is represented in Tolkien's world by Théoden, Éomer, Boromir and Denethor, whose performance is based on what can be defined as hypermasculinity, ${ }_{4}^{4}$ the second pattern seems to have assimilated some attitudes and practices that have been traditionally considered feminine, and is represented by Aragorn, Faramir, Gandalf, Frodo and Sam.

All these characters' behaviour clearly illustrates the substantial differences among them throughout the plot. On the one hand, we have the society of Rohan, where Théoden is King and Éomer is his heir (and foster son) and which is a reconstruction, according to Shippey, of the literary Anglo-Saxon world found in texts like Beowulf, The Wanderer and The Battle of Maldon (2001). It is a society that therefore inherits the epic heroic code of comitatus, which binds the warriors and the lord under ties that will lead the thanes to follow their chieftain to the battlefield and avenge his death in the event he is killed. The Rohirrim represent this code and its homocentric social organisation, this "warlike spirit" which makes "horses and riders alike radiate power, an aggressive energy and a certain authentic wildness" (Honegger 2011: 117). The introduction of these characters is mainly based on their physical and bodily qualities and prowess, and their close association with their horses helps to highlight their virility and strength. As fearless and death-seeking warriors, the Men of Rohan feel the lust of battle and aspire to die in it, for in doing so, they will achieve glory. They share this attitude with the characters in The Battle of Maldon and the importance of having a lord to guide them also appears in The Wanderer. Their heteronormative identity is inspired in a Germanic society's masculine ideal which under-

of Mirkwood, Aragorn is Elendil's heir, Boromir is the heir of the Steward of Gondor, Gimli is the son of one of the Dwarves that accompanied Bilbo in his adventure in The Hobbit, Merry is the son of the Master of Buckland, Pippin is the heir of the Thain in Tookland and Frodo is Bilbo's heir. The only character that does not seem to belong to such elite is Sam, who is "only" a gardener but whose participation in the War of the Ring will prove essential.

4 The term was first used by Donald L. Mosher and Mark Sirkin to carry out a psychological survey and analyse a "macho personality" that was defined by three variables: "(a) calloused sex attitudes toward women, (b) violence as manly, and (c) danger as exciting" (1984: 151). Although the three variables are not always found in all the characters that belong to this pattern (the first one is definitely difficult to find due to the scarcity of scenes shared with female characters), some of their attitudes make us regard their performance near the type of hypermasculinity defined by Mosher and Sirkin. 
stands that "“masculine' equals forceful, competent, competitive, controlling, vigorous, unsentimental and occasionally violent" (Heilbrun 1973: XIV).

Being brought up in this atmosphere, Éomer is undoubtedly a wonderful representative of the Rohirrim's masculinity, which is ultimately based on their military prowess, physical strength and loyalty to their lord. In Rohan we also find certain touches of the Northern heroic spirit and Tolkien's criticism of ofermod, a concept which appears in The Battle of Maldon and was translated by Tolkien as "overmastering pride." His opinion of this northern heroic code is contradictory, though, as it lies somewhere between his admiration for Old English and Norse texts and the theory of courage contained in them, and his own Christian beliefs or his own experience in WWI, above all, because the theory of courage is mainly based on despair, "its spirit often heathen ferocity" (Shippey 2003: 157). In The Lord of the Rings, the King of Rohan is a character who, when first introduced in The Two Towers, is but a shadow of his former self due to his malevolent counsellor Wormtongue's "bewitchment." Instead of a ruling king, Théoden has become Saruman's puppet. He is devoid of his physical and mental strength and has failed as a lord to his people and a (foster) father to Éomer and Éowyn.

It is in this atmosphere of absence and numbness, and devoid of the characteristic hypermasculinity of the Rohirrim that Gandalf, Aragorn, Legolas and Gimli find Théoden in Edoras. Once the King is fully recovered thanks to Gandalf, he regains not only his role as ruling king but, consequently, his masculinity and power, as the wizard encourages him to wield his sword again, a symbol of his masculinity, and is determined to go to war with his men. In part regretting what he had become for his people and his own mistakes and partly because the lust of battle is still in him, Théoden is resolute to redeem himself and find glory and honour in the battlefield.

It is not until The Return of the King that Théoden appears again in his full stature as king and warrior, as the true lord whose men will follow to death if necessary:

Now is the hour come, Riders of the Mark, sons of Eorl! Foes and fire are before you and your homes far behind. Yet, though you fight upon an alien field, the glory that you reap there shall be your own for ever. Oaths ye have taken: now fulfil them all, to lord and land and league of friendship! (RK V 5: 818)

Théoden finally dies in the Pelennor Fields, thus finding redemption and glory in the battlefield. With the king's death, there is a new king in Rohan, Éomer. Stout-hearted, suspicious and impulsive, with what Shippey calls "a streak of nomad ferocity" (2003: 127), it is among the Rohirrim that his qualities as a warrior are at its highest. He is a true representative of this epic society of Rohan, which is less learned than Gondor's: Éomer's is an "archaic warrior-society" (Honegger 2011: 118) and he is also endowed with the same type of hypermasculinity that can be found in Rohan. Concurrently, the Rohirrim portray positive values towards their lord, for whom their loyalty and love are similar to those qualities found in The Battle of Maldon. One instance of this can be found in the Pelennor

\footnotetext{
5 To make the quotations of The Lord of the Rings easy to follow and find in the original text, I make reference to them following this order: title of the volume (FR - The Fellowship of the Ring, TT - The Two Towers, RK - The Return of the King), number of the book within the volume, chapter and page.
} 
Fields, when their lord died and they also believe Éowyn to be dead - their intention to avenge them is even greater than their mourning. In an ancient society that is doomed to disappear in Middle-earth, Éomer is thus its last hypermasculine representative.

This pattern also appears in the more culturally evolved society of Gondor, which has sometimes been compared to a declined Byzantium (Librán-Moreno 2011), the differences with Rohan being quite clear with this comparison. Born as one of the most important realms in The Silmarillion, the line of Númenórean kings that ruled in Gondor faded up to a point when, as there was no claimant of pure blood to the crown, the era of the stewards started and it was settled that they would rule until the arrival of a rightful heir. Denethor becomes thus the $26^{\text {th }}$ (and last) Steward of Gondor. Many scholars have compared both the figures of Théoden and Denethor, as they share similarities that situate them as performers of an obsolete type of masculinity.

In the case of Denethor, he is described in the appendices as a "proud man, tall, valiant and more kingly than any man that had appeared in Gondor for many lives of men; and he was wise also and far-sighted and learned in lore" (1030). Denethor proves to be a ruling steward who is rather authoritarian, dominant, and imposing; he is thus a representative of a type of masculinity that is constructed on the exertion of power over everyone else through oppression and domination. He even exerts this power over his own sons, with whom he has a sort of dysfunctional relationship and does not hesitate to demonstrate his preference for his older son in public.

Although the appendices tell us that he was indeed capable of love when his wife lived, his emotional inarticulateness is nevertheless present when he addresses his son Faramir. Tolkien has endowed him with a type of emotional castration that has turned him into an estranged father and has made him delusional to a certain extent. In his feeling of superiority and jealousy for the wizard Gandalf, he becomes not only an authoritarian and distant father to Faramir but also an unjust lord, incapable of acknowledging any of Faramir's victories, always blaming him for his elder son's death. We cannot forget that Denethor is also somehow dominated by Sauron: his willing to control everything has made him use the palantír, by means of which Sauron chooses what he wants the Steward to see. We can see in Denethor a perfect example of ofermod, for, in his excessive pride he believes himself capable of "dealing" with the Dark Lord through this stone.

Denethor is a failed father and steward, more or less in keeping with the Théoden we find at the beginning of The Two Towers. The main difference between these characters is that, although Théoden finally manages to redeem himself in both roles, Denethor is nowhere near doing so. His excessive pride and obsession and his use of the palantír have turned him into a depressed character: once his son Boromir is dead, he seems to lose his mind and ends up giving into despair and later self-destruction when Faramir returns wounded from the battlefield. It is when he starts losing his own power over others that we see how he has lost his hypermasculinity and control. His despair even leads him to ask his servants to prepare a pyre for his son Faramir and himself, and although Pippin and Gandalf save Faramir in the end, Denethor prefers to commit "suicide and advises everyone else to do the same, rather than be a slave under a puppet government" (Croft 2004: 26).

As proud as his father, and another example of ofermod in Gondor, Boromir is described in Appendix A as "a man after the sort of King Eärnur of old, taking no wife and 
delighting chiefly in arms; fearless and strong but caring little for lore, save the tales of old battles" (1031) and even Éomer acknowledges that he is more like the hypermasculine Rohirrim than the Men of Gondor. He shares with Éomer this hypermasculinity, based on his physical strength and power.

Jane Chance refers to Boromir's evolution in The Lord of the Rings as a sort of moral deterioration (2010), as if his excess of pride and his lack of lore and humility had doomed his future from the very beginning. Suspicious of Aragorn, whom he learns in the Council of Elrond is the rightful king, for so long awaited in Gondor, he feels threatened by him from the very first moment they meet. He sees his own superior hierarchical status in Gondor lost now that the king-to-be has come, his power and masculinity stand challenged. His moral deterioration reaches its peak when he understands that the Fellowship of the Ring will not go to Minas Tirith, which was his initial purpose, so he tries to take the Ring from Frodo. On the one hand, this action is based on his patriotic attempt to save his people but at the same time, he has completely fallen into temptation and believes himself capable of controlling it, thus is his pride, for he knows that the only way he can get his status and power back is by taking the One Ring from the hobbit. As Wayne G. Hammond and Christina Scull describe him, Boromir is "a tragic figure with many good qualities but with weaknesses that lay him open to temptation. The Ring has been able to play on his wish to save his country and on his desire for personal glory" (2005: 349). Boromir's end is nevertheless different from his father's, since, although he does give in to temptation and despair, he also manages to redeem himself when he tries to save Pippin and Merry from some Orcs; he finally achieves a good death after showing his repentance to Aragorn.

The deaths of Théoden, Denethor and Boromir thus mark the end of the era of hypermasculinity and some of the values it is based on. The War of the Ring means the end of the Third Age and the beginning of the Fourth Age, characterized by the Dominion of Men, so with the end of hypermasculinity, not only can we see the end of a historical period in Middle-earth, but also the end of some of the characteristics that are usually found in a dominant hegemonic masculinity. Does this mean that there is a "crisis of masculinity" in The Lord of the Rings? To start with, by using this the term, we would be asserting that there is only one type of masculinity and not masculinities. So instead of a "crisis", I would rather propose the hypothesis that the Third Age means the end of a dominant type of hegemonic (hyper)masculinity in favour of more evolved patterns. Hypermasculinity, which is rather based on death as a means to achieve personal glory seems to be quite a destructive pattern, for it bases its power on the eventual destruction of others or even oneself. It is a type of hegemonic masculinity which aims at exerting some manly virtues, considering that danger is exciting, and is characterized by competitiveness and heroic achievement. Nevertheless, in the end it proves to be far from what will save Middle-earth, that is to say, the patterns of masculinity portrayed by characters such as Aragorn, Faramir, Gandalf and some of the hobbits.

This second pattern I would like to explore now can be socially situated in Middle-earth within the pattern of "alternative masculinities," "for it does not conform to traditional

\footnotetext{
6 Research about alternative masculinities within the field of the studies of masculinities has been carried out by various scholars who have presented them as opposed to other dominant types and other hegemonic patterns
} 
patterns. The type of masculinity that characters like Aragorn, Faramir, Gandalf, Sam and Frodo are endowed with is characterized by placing itself far from the hegemonic model represented by Denethor, a character with whom Aragorn and Faramir share more than the others. Their pattern is based on two relevant aspects: their will to preserve life and their peaceful attitudes. Once again in this analysis, Tolkien's experience in the Great War proves essential in the understanding of the construction of this pattern, for although Tolkien did fight in the First World War, as Benvenuto remarks, "although not a 'pacifist' in modern terms, Tolkien grew to detest it, as he knew firsthand the pain and misery it wreaked on people" (2006: 50).

Aragorn and Faramir, the rightful heir that Gondor had awaited for so long and the Steward of Gondor's younger son, respectively, are considerably closer in their behaviour and attitudes towards life than Faramir and his own brother Boromir. This enhances the idea that masculinity is not static but fluid and influenced by a person's circumstances and upbringing, for example. Aragorn and Faramir have received valuable lessons in their lives from Gandalf and in the case of Aragorn, not only from the Wizard but also from the Elves, with whom he lived for some years. They have thus inherited from them the respect for all living creatures and the idea that fighting should be resorted to only in case it is necessary - they represent Tolkien's own ideas, above all Faramir, for as the author admitted in a letter in 1956: "As far as any character is 'like me' it is Faramir" (Carpenter 1995: 232).

Aragorn has grown up with different types of identities, which he uses at his free will: he is Estel for the Elves, Strider in Bree and his true self, Aragorn, for those that are well aware of his lineage. When the hobbits first meet him and he is introduced from their hobbito-centric perspective, all we know about him is based mainly on his looks, which are those of a Ranger of the North, a "strange-looking weather-beaten man, sitting in the shadows near the wall" (FR I 9: 153). Completely unnoticed from his position, he chooses this personality to introduce himself to the hobbits - it is not until he deems it necessary that he shows himself as whom he really is, Isildur's heir. Tolkien created the character in layers that he removed as his time to be crowned as king approached.

Being the heir to the throne of Gondor is not an easy task for Aragorn and he must fulfil several tasks before he is ready to claim the throne - his fate lies in that moment, as it will only be then that he will also be able to marry Arwen, once he has proved worthy of his lineage. First of all, he must have his broken sword, the shards of Narsil, Isildur's sword, forged again. This could be seen as a metaphor of his own masculinity - since the phallic symbol is broken, Aragorn's own image is not complete: it will not be until Narsil is re-forged that we begin to have the first glimpses of his masculinity in full. Secondly, he must prove himself capable of healing others, which he already does in several instances in the book, mainly with Frodo, but it will be in Gondor and with the use of athelas that he is able to heal Merry, Faramir and Éowyn.

The hierarchy of the Fellowship of the Ring is inherently clear from the beginning and, as Gandalf and Aragorn are the characters that seem to hold the highest power, they

of masculinities (Flecha, Puigvert and Ríos 2013, Armengol and Carabí 2014). Concerning The Lord of the Rings, John Miller has suggested the presence of this type of masculinities in Middle-earth, which is different from the hegemonic type represented by Aragorn. He has seen the Elves, for instance, as representatives of this alternative masculinity (2003: 191). 
become the main leaders of the group. Using Northrop Frye's analysis, they are heroes of the high-mimetic mode with whom it is difficult to identify but, at the same time, Aragorn is not a flawless character. Although the image of an Aragorn that has doubts is heightened in Jackson's film adaptation, ${ }^{7}$ in the book there are also some moments in which he hesitates on what course of action to follow or he doubts his own decisions, like in Amon Hen, where he states that "all that I do goes amiss" (TT III 1: 403), or when Boromir dies, as he sees he has failed as a leader: "It is I that have failed. Vain was Gandalf's trust in me" (TT III 1: 404). Boromir's death, together with Frodo and Sam's escape and the kidnapping of Merry and Pippin, mark the breaking of the Fellowship, which, according to Crocker, is partly due to Aragorn's personal failure and his "momentary indecision [whether to follow Frodo or save Merry and Pippin] shows that he is not yet ready to assume his role as leader" (2005: 119).

Despite all his failures or indecisions, Aragorn is a very charismatic leader, always followed by Legolas and Gimli, mainly because of the respect and love they feel for this character. As the plot progresses, so does Aragorn - according to Janet Brennan Croft, Aragorn represents the ideal king for Tolkien, with all his experience in the battlefield, he proves in the end that he is a worthy leader and king, although the throne was nevertheless his by "right of birth" (2004: 91).

Although the Fellowship of the Ring starts from Rivendell to achieve Frodo's quest, which is to destroy the Ring, we also witness Aragorn's own quest. He never loses his role as protector of the hobbits to fulfil his own tasks - he vows to protect the hobbits from the very beginning even with his life, "if by life or death I can save you, I will" (FR I 10: 168 ), and that is what he does. He never uses his superiority or authority over others and never tries to dominate the weaker characters, he is never proud or impulsive and even in his worst moments, he never falls into despair - he is thus far from the hypermasculine Boromir, Éomer and Denethor. As aforementioned, his upbringing among Elves and his relationship with Gandalf may be in part responsible for this.

In this sense, Faramir, contrary to what one may believe a priori considering that he is Denethor's son and Boromir's younger brother, is also far from his father and brother's hypermasculinity. In the same way as Aragorn has been significantly influenced by the Elves and Gandalf, Faramir has also had the Wizard as a mentor in his life and this has made his views closer to the Wizard's than his own father's. Despite his estranged relationship with Denethor, this has not turned him into a resentful or vengeful son. On the contrary, not even the fact that his father openly showed his favouritism for his brother affected the brothers' relationship - Humphrey Carpenter describes Faramir as "courageous and decisive but also modest, fair-minded and scrupulously just and very merciful" (1995: 323). Whereas Boromir is closer to a warrior found in an Old English text, whose masculinity is based on his military prowess and physical strength, Faramir is similar to an Arthurian character, more interested in learning and with a "keen wit" (TT IV 5: 648).

\footnotetext{
The director's interpretation of this character varies from Tolkien's as Jackson creates an Aragorn that is rather a low-mimetic hero. Moreover, although the cinematic Aragorn is a self-doubting hero that is reluctant to accept his fate, Tolkien's character is never hesitant concerning his future as king of Gondor.
} 
Faramir is curious and intuitive, he is not impulsive, so he ponders on his decisions carefully and he is so witty that he can infer many things just by reflecting upon the matter. Thus, despite the fact that Frodo never told him that his brother had fallen into temptation, he did infer that Boromir's fate was linked to Frodo. He is culturally superior to the Rohirrim, a true representative of a society that is, notwithstanding its decline, more sophisticated than Rohan's. Moreover, in his rejection of militarism, he also represents Tolkien's own ideas concerning the belief in the just war cause. They were not completely against the idea of war but it should only be an option or regarded as a solution if strictly necessary, in Faramir's words: "War must be, while we defend our lives against a destroyer who would devour all; but I do not love the bright sword for its sharpness, nor the arrow for its swiftness, nor the warrior for his glory. I love only that which they defend" (TT IV 5: 656).

Much of what Faramir knew was taught by Gandalf. The Wizard, a Maia or angelic being, as Tolkien defined him himself, also shares with Aragorn and Faramir some similarities. His relationship with the characters that are part of these alternative masculinities is so important that it would be impossible to understand them without knowing that Gandalf influences them. Like Aragorn, his identity varies depending on where he is or who he is talking to: he is a powerful Istari for the Elves, Mithrandir in Gondor and an eccentric fireworks maker for the hobbits. He also chooses to reveal himself as he really is whenever he sees it convenient. As the story is hobbito-centric, we first meet him through the hobbits' eyes as an old man who is in charge of making fireworks at Bilbo's birthday party. He is described as the Jungian archetype of the "old wise man": "he wore a tall pointed blue hat, a long grey cloak and a silver scarf. He had a long white beard and bushy eyebrows that stuck out beyond the brim of his hat" (FR I 1:24), similar to King Arthur's Merlin and also Odin.

As readers, we only begin to know the extent of his power when he "resurrects" after his fight with the Balrog in Moria. ${ }^{8}$ However, despite his patent superiority over the rest, he never uses it unless completely necessary. He hides his own power behind his old age, for example, in Meduseld, where against Théoden's wishes he is allowed to enter the hall with his staff. Also here, Gandalf's staff, which could be regarded as a phallic symbol, is an extension of his own masculinity and inner strength and which he uses to exert his power.

Gandalf also represents a father-figure for the hobbits and he is not only a mere friend - he protects them and is like a counsellor or guide for them. He adopts some paternal attitudes towards them: he is caring and protective, he worries about them and does not hesitate to reprimand them, as in the case of Pippin. As a mentor, he tells Frodo that "many that live deserve death. And some that die deserve life. Can you give it to them? Then do not be too eager to deal out death in judgement" (FR I 2: 58), in an attempt to make him see the importance of life and how he should not be hasty in regretting that Bilbo never killed Gollum. At the end of the story, he proves right, for it is thanks to Gollum that the One Ring is finally destroyed.

Like Aragorn and Faramir, he also wants to preserve life, thus representing the opposite of what Saruman wants to do, which is to dominate the world and turn it into an indus-

\footnotetext{
8 According to Hammond and Scull, Tolkien did not want readers to compare Gandalf's resurrection with Christ's (2005: 395). However, the very essence of his fall with the Balrog and his coming back make it inevitable not to do so.
} 
trialized place at his own convenience. These characters, Aragorn, Faramir and Gandalf, embrace traits that have traditionally been ascribed as feminine, differentiating thus their type of masculinity from a dominant hegemonic one. They are all good representatives of compassion, honour, duty, wisdom, mercy, justice, and humility. ${ }^{9}$ Although heteronormative in essence, they do not represent any of the negative aspects that are usually associated with a dominant hegemonic masculinity - they do not exert their power over others, they do not see the rest of the Fellowship of the Ring as subordinates and do not try to oppress them but, at the same time, they are well aware that if it is necessary to fight, they will not refuse it. Life is above everything else for them, so Edith L. Crowe also suggests that

Tolkien's ecological consciousness was ahead of its time and in many ways worthy of a contemporary ecofeminist. The nurturing values of home and hearth may be more frequently ascribed to females but they are given great importance and respect, not denigrated as they are so often in the Primary World (in Reynolds and GoodKnight 1995: 277).

There are also other characters that share these life-preserving attitudes: the hobbits, above all in the case of Sam and Frodo. Born as a race created by Tolkien, in contrast with Elves, Dwarves or Wizards, who appear in other fantasy books, the hobbits are an extension of Tolkien and their Shire resembles the author's childhood's Warwickshire. Pipe smokers, food lovers, good-hearted and enemies of anything modern, they prove to be a very tough race despite their weak appearance due to their short height and child-like looks.

John Garth believes indeed that Tolkien "could model hobbits directly on English people as he had known them in and around his cherished childhood home on Sarehole near Birmingham, borrowing aspects of custom, society, character and speech" (2004: 307). The hobbits are the unexpected heroes of the story and it is thanks to the inner strength of their race that they manage to overcome the hardest situations.

The four hobbits that embark on the quest to destroy the Ring could be seen to represent the young soldiers who enlisted in the Great War and who went to the battlefield without knowing completely what a war was really like. In the case of Sam and Frodo, they have also been compared to a soldier and his batman due to their relationship. The hobbits therefore share a nonchalant attitude which changes gradually as the quest goes on, as for them this becomes a journey into maturity.

Their carefree nature, their love of laughter, their display of emotions and their earthiness are probably qualities that make some readers identify with them, also because we see the story through their eyes. Nevertheless, although they share all these traits, their evolution in The Lord of the Rings is slightly different and this will be marked by the breaking of the Fellowship.

When Boromir falls into temptation and tries to take the One Ring from Frodo, the hobbit takes the decision to leave his friends behind in an attempt to protect them. How-

\footnotetext{
9 I would like to highlight that within this alternative type of masculinity that Tolkien favours, there are also two female characters that fit in the description: Éowyn and Galadriel, who also enact some masculine attitudes in different stages of Tolkien's works, thus confirming Judith Halberstam's theory that female masculinity is possible. Like Aragorn, Gandalf, Faramir, Sam and Frodo, they decide to embrace more environmentally positive and life-preserving attitudes, far from the negative hegemonic type of masculinity that favours dominance and violence. For space reasons, this will be discussed in another essay.
} 
ever, his faithful servant Sam cannot allow such a thing and goes with him on his journey to Mount Doom. Merry and Pippin, on the other hand, find themselves ambushed by orcs and despite Boromir's effort to save them, which costs him his life, they are kidnapped by the foul creatures. The hobbits' paths separate and their individual journeys into maturity start; the situations that they will experience are bound to bias their evolution and the type of masculinity they will perform when they go back to the Shire.

The practical Merry and the naïf Pippin live different adventures until they reunite with their friends again and return to their beloved Shire: they are kidnapped by the Urukhai, they meet Treebeard, an essential moment because the Ents will be roused after this encounter, and, finally, they show their fealty to the King of Rohan and the Steward of Gondor, respectively. According to Shippey, they are "military unambitious" (2001: 151), so when Merry decides to offer his service to Théoden, it is out of his love for the king and not because he really wants to become a Rohirrim. Théoden's attitude towards the hobbit is rather protective, so he leaves him behind with Lady Éowyn instead of allowing him to go to battle. Nevertheless, as Merry is determined to fight, he does not hesitate to accept the invitation of a young warrior, Dernhelm, to go to the battlefield with him. This will become one of the most important moments in the War of the Ring, for the young warrior is not just another Rohirrim but Éowyn, and Merry is a hobbit that would do anything for his king and the Lady of Rohan, so they end up killing the Lord of the Nazgûl together in the battlefield.

Down-to-earth, practical, responsible, thoughtful and mature, Merry represents everything that Pippin is not, as the younger hobbit is more impulsive and less mature (Hammond and Scull 2005: 118). It is out of this impulsiveness that he decides to swear fealty to Denethor, maybe in an attempt to repay him for Boromir's death, who gave his life to protect both hobbits. This moment contrasts with the close moment between Merry and Théoden, for Denethor accepts the hobbit's service with a cold and distant attitude. Pippin's evolution reaches its climax when he helps to save Faramir from being burnt in a pyre by his father, telling Gandalf of Denethor's plans.

Both Merry and Pippin undergo a process which Joseph A. Kestner divides into four stages concerning British adventure fiction: departing, encountering, transgressing and potential reintegrating. We can see here some similarities with Joseph Campbell's stages of a hero as well: departure, initiation and return. In these stages the two characters end up accepting certain codes of masculinity which are not usually ascribed to hobbits.

Sam and Frodo, on the other hand, follow their own journey into maturity together and apart from other characters, except for Gollum. Initially regarded as insignificant characters, Gandalf understands that even those that seem to be weaker are capable of the most outstanding actions. As a soldier and his batman, Frodo and Sam's relationship also progresses as they approach Mount Doom although Sam's servile attitude never changes; whereas he actually left the Shire as Mr Frodo's servant and friend, we manage to see Sam adopting some mother-like attitudes at some stage. Aware of the torture that Frodo must endure, physically and mentally, Sam is in charge of making him rest, sleep and eat - they are the vivid image of two foot soldiers in the First World War (Hammond and Scull 2005: 610): completely worn out, with scarce provisions left and little hope of survival.

Sam always puts Frodo first and when he believes that Shelob has killed him, he has to face something which had never occurred to him: that he would be left alone and that 
his master would die. When he later learns that Frodo is actually alive, he manages to save him from the orcs and they both continue their journey to Mount Doom. Once they are there, his master completely exhausted, Sam even carries him to the Cracks of Doom, a moment which Anne C. Petty defines as a "proof of the deep level of his commitment to Frodo" (2003: 204).

Sam's evolution in the story is quite surprising: from the hobbit eager to see the Elves in The Fellowship of the Ring, we follow his progression until he also becomes a Ring-bearer and manages to take his master to the end of his quest. He follows thus Campbell's process of a hero, with a departure, initiation and return. His loyalty towards his master never falters, to such an extent that it

expands into a higher type of love - the Green concept of agape. Sam truly does become his brother's keeper in the biblical sense; his display of self-sacrifice to protect and support his companion is done out of genuine love for another person, not for any external gain to himself (Petty 2003: 203).

Frodo's sense of sacrifice is what makes him embark on the quest to destroy the Ring, for he knows that if he remains in the Shire, his friends are in danger. It is only near the end that he becomes aware of the fact that if he saves the Shire, it will be for others and not for him. In his quest, his suffering is not only physical (he is stabbed, bullied, jabbed) but, above all, mental, for every step he takes nearer the destruction of the Ring, his will begins to falter and it becomes more and more difficult for him. In this sense, his journey could be compared to the Biblical Stations of the Cross.

Frodo's quest is also a process of learning: he learns from Gandalf and other characters the importance of mercy, which kept Gollum alive until the very end and which, indirectly, is responsible for the destruction of the Ring. Nevertheless, he has carried the Ring for so long and has had to resist the temptation to wear it so many times that by the time he reaches the Cracks of Doom, he is completely lost and decides not to fulfil his quest. His will finally falters, after all he has gone through and it is Gollum that bites his finger and accidentally falls in the fire that destroys the Ring.

Frodo goes back home emasculated, shell-shocked and disillusioned,${ }^{10}$ for nobody really acknowledges what he and his friends have achieved. He is again the reflection of a First World War soldier, for whom there is no happy or "eucatastrophic" ending. In a way this could be understood as a type of punishment for having failed to fulfil his quest in the end.

As the hobbits undergo different rites of initiation, the evolution of the types of masculinities they perform also differs - this is obvious when they go back to the Shire and see that it has been taken over by ruffians and Shirriffs. This situation shows us how Merry and Pippin are worthy representatives of the societies they have showed fealty to, for they decide to lead a battle against their enemies and recover the management of the Shire. They have grown to represent the archetype of the Warrior (Moore and Gillette 1990), as they do not hesitate to fight to protect their homeland. Merry leads this rebellion and is since then remembered as Captain Meriadoc. Even Sam fights against the Shirriffs, whereas Frodo decides not to take any active part in this battle as he is against fighting "if it can be helped"

10 Shippey compares Frodo's return with the "disillusionment of the returned veteran" (2001: 156). 
(RK VI 9: 983) and "unless it must be done, to prevent them from hurting hobbits" (RK VI 9: 987). His passivity thus contrasts with the "masculine aggressiveness of Sam, Merry and Pippin" (Keenan 1969: 69). He has become indeed a pacifist who wants to prevent any sort of violence, dissociating thus the traditional link between men and violence.

Both Frodo and Sam end up embracing the live-preserving attitudes of Faramir,Aragorn and Gandalf, which have already been mentioned. In the case of Sam, he is also responsible for the reconstruction of the Shire, thanks to Galadriel's gift. He adopts an environmental attitude, which Matthew Dickerson and Jonathan Evans deem essential as "in fulfillment of a prediction by Frodo, Sam becomes not only a great gardener but also a forester - which in the Shire involves the planting of trees, not the felling of them" (2006: 231). He becomes, in Dickerson and Evans' words, the "hero of the reconstruction" of the Shire (2006: 18). Moreover, he has become the archetype of the Healer.

Their interaction with other races and their learning and maturity process will determine the patterns of masculinity they will perform at the end of the book. Whereas they still emphasize the importance of friendship and bonding when they go back home, the war has left scars on them that will influence their behaviour forever and, metaphorically speaking, it has brought Merry and Pippin closer to Rohan and Gondor, rather than Hobbiton.

After analysing and re-reading The Lord of the Rings from the point of view of gender, it seems clear to me that in Tolkien's text we can see a pattern of masculinity performed by characters like Boromir or Denethor, who are nearer death, which seems to be as a type of hegemonic masculinity within Middle-earth and proves to be obsolete at the end of the Third Age. As Middle-earth is saved by characters who enact a new pattern of masculinity that embraces a life-preserving attitude, Tolkien seems to be thus in favour of the performance of a type of masculinity that is rather based on simplicity, loyalty, friendship and mercy; it is based on life rather than death, peace rather than war. The characters that represent this pattern are heroic, although not flawless, they are respectful, honest and cooperative; they represent thus a different type of heroism as well. The Fourth Age is therefore in the hands of characters that encompass both feminine and masculine positive traits - despite the fact that Men still hold socially the power in Middle-earth, King Elessar does not see any of his companions from the Fellowship of the Ring as subordinates, for instance, as in the case of the hobbits, he bows to them:

And then to Sam's surprise and utter confusion he bowed his knee before them; and taking them by the hand, Frodo upon his right and Sam upon his left, he led them to the throne, and setting them upon it, he turned to the men and captains who stood by and spoke, so that his voice rang over all the host, crying: 'Praise them with great praise!' (RK VI 4: 933).

Written by a conservative author who has been "criticized, attacked, explained, forgiven and mainly misunderstood when it comes to the matter of women" (Michel 2006: 56), but whose male characters have never been regarded as perfect either, an analysis from the perspective of gender provides quite an interesting approach to a text that has been mainly criticized by its scarcity of female characters. By introducing important feminine traits in male characters, Tolkien introduces types of masculinities that are not purely dominant, offering models that can be seen as alternative or non-hegemonic. Sixty years after its 
publication, the foregoing analysis has tried to show that some male characters perfectly embody masculine and feminine traits at the end of the Third Age and beginning of the Fourth Age, marked by the disappearance of Elves from Middle-earth and the start of the Dominion of Men, offering thus a richer and deeper understanding of The Lord of the Rings.

\section{REFERENCES}

Armengol, J. M. 2006. Gendering Men: Theorizing Masculinities in American Culture and Literature. Barcelona: Universidad de Barcelona.

Benvenuto, M. R. 2006. "Against Stereotype: Éowyn and Lúthien as $20^{\text {th }}$-Century Women." Tolkien and Modernity. Eds. F. WeInREICH and T. Honegger. Zollikofen, Switzerland: Walking Tree. 31-54.

ButLer, J. 1999. Gender Trouble: feminism and the subversion of identity. London and New York: Routledge.

Carabí, A., and J. M Armengol, eds. 2014. Alternative Masculinities for a Changing World. New York: Palgrave Macmillan.

Croft, J. B. 2004. War and the Works of J.R.R. Tolkien. Westport, Connecticut, London: Praeger.

CAmpbell, J. 1993. The Hero with a Thousand Faces. London: HarperCollins.

CARPENTER, H, ed. 1995. The Letters of J.R.R. Tolkien. London: HarperCollins.

Connell, R.W. 1995. Masculinities. Cambridge: Polity.

Connell, R.W. and J. W. Messerschmidt. 2005. "Hegemonic Masculinity. Rethinking the Concept." Gender \& Society. Vol. 19 No.6. 829-859.

Chance, J. 2010. The Lord of the Rings: The Mythology of Power. Lexington, KY, USA: University Press of Kentucky.

Crocker, H. A. 2005. "Masculinity.” Reading The Lord of the Rings. New Writings on Tolkien's Classic. Ed. R. Eaglestone. London and New York: Continuum. 111-123.

Crowe, E. L. "Power in Arda: Sources, Uses and Misuses." Proceedings of the JRR Tolkien centenary Conference 1992, Keble College, Oxford, 1992. Eds. P. REYNOLDS and G. H. GoodKnight. Milton Keynes: Tolkien Society. 272-277.

Frye, N. 1957. Anatomy of Criticism: Four Essays. Princeton: Princeton University Press.

Dickerson, M. and J. Evans. 2006. Ents, Elves and Eriador. The Environmental Vision of J.R.R. Tolkien. Kentucky: The University Press of Kentucky.

Flecha, R., L. Puigvert, and O. Ríos. 2013. "The New Alternative Masculinities and the Overcoming of Gender Violence." International and Multidisciplinary Journal of Social Science 2.1: 88-113. 
GaRth, J. 2004. Tolkien and the Great War. The Threshold of Middle-earth. London: HarperCollins.

Hammond, W. G. and C. Scull. 2005. The Lord of the Rings. A Reader's Companion. London: HaperCollins.

Hearn, J. and D.L. Collinson. 1994. "Theorizing unities and differences between men and between masculinities." Theorizing Masculinities. Eds. H. Brod and M. Kaufman. Thousand Oaks, London, New Delhi: Sage. 97-118.

Heilbrun, C. G. 1973. Towards Androgyny. Aspects of Male and Female in Literature. London: Victor Gollancz.

Honegger, T. 2011. “The Rohirrim: 'Anglo-Saxons on Horseback?' An Inquiry into Tolkien's Use of Sources." Tolkien and the Study of his Sources: Critical Essays. Ed. J. FisheR. Jefferson, North Carolina and London: McFarland \& Company. 116-132.

KeEnAn, H. T. 1969. "The Appeal of The Lord of the Rings: A Struggle for Life.” Tolkien and the Critics: Essays on JRR Tolkien's The Lord of the Rings. Eds. N. D. IsAACS and R. A. Zimbardo. Notre Dame: University of Notre Dame. 62-80.

Kestner, J. A. 2010. Masculinities in British Adventure Fiction, 1889-1915. Farnham and Burlington: Ashgate Publishing.

MacInnes, J. 1998. The End of Masculinity. The Confusion of Sexual Genesis and Sexual Difference in Modern Society. Buckingham, Philadelphia: Open University Press.

Michel, L. 2006. "Politically Incorrect: Tolkien, Women, and Feminism.” Tolkien and Modernity. Eds. F. WeinREICH and T. HonEGgER. Zollikofen, Switzerland: Walking Tree. 55-76.

Miller, J. 2003. “Alternative Masculinities in The Lord of the Rings.” Images of Masculinity in Fantasy Fiction. Ed. S. FendLER and U. HorstMANN. Lewiston, Queenston, Lampeter: The Edwin Mellen Press. 183-203.

Mosher, D. L., and M. SiRKin. 1984. "Measuring a Macho Personality Constellation." Journal of Research in Personality 18: 150-163.

Petty, A. C. 2003. Tolkien in the Land of Heroes. New York: Cold Spring.

SHIPPEY, T. 2001. J.R.R. Tolkien. Author of the Century. London: HarperCollins. 2003. The Road to Middle-earth. How J.R.R. Tolkien created a New Mythology. New York: Houghton Mifflin.

StraubhaAR, S. B. 2004. "Myth, Late Roman History, and Multiculturalism in Tolkien's Middle-earth." Tolkien and the Invention of Myth. Ed. J. Chance. Lexington, KY, USA: University of Kentucky Press. 101-118.

Tolkien, J.R.R. 1991. The Lord of the Rings. London: HarperCollins. 